\title{
Endovascular treatment of subclavian stenosis - single center experience
}

\author{
Savko Dobrota ${ }^{1}$, Luka Filipović - Grčić ${ }^{1}$, Dražen Perkov ${ }^{1}$, Vesna Đermanović Dobro- \\ ta $^{2}$, Vesna Lukinović - Škudar ${ }^{3}$, Majda Vrkić Kirhmajer ${ }^{4,5}$, Neva Coce ${ }^{1}$, Silva Butković \\ Soldo ${ }^{6,7}$ \\ 1. Department of Diagnostic and Interventional Radiology, University Hospital Center Zagreb, Zagreb, Kišpatićeva 12, Croatia; \\ 2. Department of Diabetic Complication, Clinical Hospital Merkur - University Clinic Vuk Vrhovac, Zagreb, Zajčeva 19, Croatia; \\ 3. Department of Physiology, School of Medicine, University of Zagreb, Zagreb, Šalata 3, Croatia; \\ 4. Department of Cardiovascular Diseases, University Hospital Center Zagreb, Zagreb, Kišpatićeva 12, Croatia; \\ 5. Medical Faculty, School of Medicine, University of Zagreb, Zagreb, Šalata 3, Croatia; \\ 6. Department of Neurology, Medical Faculty, University of Osijek, Osijek, Josipa Huttlera 4, Croatia; \\ 7. Department of Neurology, Clinical Hospital Center Osijek, Osijek, Josipa Huttlera 4, Croatia;
}

OPEN ACCESS

Correspondence:

Savko Dobrota

savko. dobrota@gmail.com

orcid.org/0000-0003-0785-5143

This article was submitted to RAD

CASA - Medical Sciences

as the original article

Conflict of Interest Statement: The authors declare that the research was conducted in the absence of any commercial or financial relationships that could be construed as a potential conflict of interest.

Received: 10 May 2021 Accepted: 18 May 2021 Published: 15 June 2021 Dobrota S, Filipović - Grčić L, Perkov D, Đermanović Dobrota V, Lukinović Škudar V, Vrkić Kirhmajer M, Butković Soldo S, Coce N. Endovascular treatment of subclavian stenosis - single RAD CASA - Medical Sciences. $547=54-55$ (2021): 32-37 DOI: https://dx.doi.org/10.21857/ m8vqrtqv89

Copyright (C) 2021 Dobrota S, Filipović - Grčić L, Perkov D, Đermanović Dobrota V, Lukinović

- Škudar V, Vrkić Kirhmajer M, Butković Soldo S, Coce N. This is an open-access article distributed under the terms of the Creative Commons the terms of the Creative Commons Attribution License (CC BY). The use, distribution or reproduction in other forums is permitted, provided the original author(s) and the copyright owners(s) are credited and that the original publication in this journal is cited, in accordance whit accepted adacemic practice. No use, distribution or reproduction is permitted which does not comply with these terms.

\section{ABSTRACT:}

Introduction: Subclavian artery stenosis is a potential cause of serious morbidity, endangering the upper extremities, brain and the heart. It is a relatively rare form of peripheral arterial disease, usually present in patients who already suffer from peripheral arterial disease on other vessels, most often lower extremity arteries. Atherosclerosis is considered to be the primary underlying cause. The current treatment of choice is endovascular approach which combines percutaneous transluminal angioplasty and stenting as its noninvasive nature yields faster recovery and less complications.

Aim: The aim of this study was to examine the characteristics of subclavian atherosclerotic lesions in patients who underwent endovascular procedure and their relationship with known risk factors. Additional aim was to assess clinical and procedure characteristics of patients and compare them with similar experiences from other centers.

Patients and methods: We conducted a retrospective single center review of patients treated with endovascular procedure for SA stenosis and/or occlusion. A total of 53 patients were detected. Three patients were excluded due to the arteritis origin of the stenosis, leaving 50 patients suitable for analysis. Participants' characteristics were analyzed using descriptive statistics. Normal distribution was assessed using Shapiro-Wilk test. Categorical variables were analyzed using the Chi-square test. Univariate logistic regression was used to calculate unadjusted odds ratios of factors associated with level of stenosis. Results: The mean age at the time of the first intervention was $62 \pm 8$ years. All except 8 patients were symptomatic. The most common symptoms were paresthesia (32\%), vertigo (30\%), muscle fatigue $(24 \%)$ and rest pain (22\%). 58\% of patients presented with Subclavian steal syndrome. The most common comorbidities and risk factors present in selected patients were hypertension $76 \%$, smoking $60 \%$, hyperlipidemia $60 \%$ and coronary artery disease $22 \%$. A total of 50 lesions were treated with 59 endovascular procedures, 9 reinterventions among them. Technical success was achieved in $85 \%$ of procedures. After univariate analysis 3 items were detected suitable for multivariate logistic regression. The multivariate regression model was statistically significant $\chi 2(4, N=50)=17.94, \mathrm{p}<0.01$, explaining $42.7 \%$ of variance (Nagelkerke $\left.R^{2}=.427\right)$. Female gender $(\mathrm{p}<0.05)$, hypertension $(\mathrm{p}<0.05)$ and smoking status $(\mathrm{p}<0.05)$ were independently associated with occlusion. Women had 7.7 times the odds of developing occlusion compared to males. Moreover, patients with a history of hypertension were 5.1 times more likely to develop occlusion. Smoking was associated with 7.8 higher chances to develop occlusion. The results of multivariate analysis are of limited significance due to the small sample size. 
Conclusion: Comparing this review with other similar studies, most of the clinical and demographic indicators were inconspicuous. Technical success was achieved in $85 \%$ of the procedures in our center, whereas in other studies it was markedly higher, ranging from $93 \%$ to $98 \%$. Female gender was identified as an additional independent risk factor, although the relevant literature indicates male gender as the risk factor. Although hyperlipidemia is a known risk factor for atherosclerotic stenosis, it did not reach statistical significance in univariate analysis. This research provided a much needed insight into the characteristics of patients and effectiveness of interventions undertaken in our center.

KEYWORDS: subclavian stenosis, subclavian artery, occlusion, endovascular intervention, hypertension, gender, smoking, hyperlipidemia, stenting, angioplasty

\section{SAŽETAK:}

ENDOVASKULARNO LIJEČENJE STENOZE POTKLJUČNE ARTERIJE - ISKUSTVO JEDNOG CENTRA

Uvod: Stenoza potključne arterije je potencijalni uzrok ozbiljnog oboljenja koje može ugrožavati gornje ekstremitete, mozak i srce. Ona predstavlja relativno rijedak oblik periferne arterijske bolesti i obično je prisutna u bolesnika koji već imaju zahvaćene druge žile, najčešće na donjim ekstremitetima. Ateroskleroza se smatra glavnim uzrokom ove bolesti. Današnja metoda izbora u liječenju kombinira perkutanu transluminalnu angioplastiku sa stentiranjem koje zbog svojih neinvazivnih svojstava polučuju brži oporavak s manje komplikacija.

Cilj: Cilj ovog istraživanja je proučiti karakteristike aterosklerotskih lezija u pacijenata koji su imali endovaskularni zahvat te njihov odnos s poznatim čimbenicima rizika. Dodatni cilj bio je procijeniti karakteristike samih zahvata i usporediti ih sa sličnim istraživanjima iz drugih centara.

Ispitanici i metode: Proveli smo retrospektivno unicentrično istraživanje pacijenata liječenih endovaskularnim zahvatima zbog stenoze i/ili okluzije potključne arterije. Od 53 pacijenta troje je isključeno uslijed arteritisa, ostavivši ukupno 50 pacijenata pogodnih za daljnju analizu. Karakteristike pacijenata analizirane su pomoću deskriptivne statistike. Normalna distribucija procijenjena je koristeći ShapiroWilk test. Kategorijske varijable analizirane su pomoću Hi-kvadrat testa. Univarijatna logistička regresija korištena je za računanje neprilagođenih omjera šansi faktora povezanih sa stupnjem stenoze.

Rezultati: Srednja dob prilikom prve intervencije bila je $62 \pm 8$ godina. Samo 8 pacijenata je bilo asimptomatsko. Najčešći simptomi bili su parestezije (32\%), vrtoglavica (30\%), mišićni umor (24\%) i bol u mirovanju (22\%). 58\% patients imalo je Subclavian steal sindrom. Najčešći komorbiditeti i čimbenici rizika bili su hipertenzija $76 \%$, pušenje $60 \%$, hiperlipidemija $60 \%$ te koronarna arterijska bolest 22\%. Ukupno 50 lezija liječeno je u 59 endovaskularnih postupaka, među njima 9 reintervencija. Tehnički uspjeh postignut je u $85 \%$ slučajeva. Nakon univarijatne analize 3 faktora su se pokazala pogodnima za multivarijatnu logističku regresiju. Multivarijatni regresijski model pokazao je statističku značajnost $\chi 2(4, N=50)=17.94, \mathrm{p}<0.01$, objašnjavajući $42.7 \%$ varijance (Nagelkerke $\left.R^{2}=.427\right)$. Ženski spol $(\mathrm{p}<0.05)$, hipertenzija $(\mathrm{p}<0.05)$ i pušački status $(\mathrm{p}<0.05)$ bili su neovisno povezani $s$ okluzijom. Žene su imale 7.7 puta veće šanse za razvoj okluzije u usporedbi s muškarcima. Pacijenti s hipertenzijom u anamnezi imali su 5.1 puta veću vjerojatnost za razvoj okluzije. Pušenje je u 7.8 puta češće uzrokovalo okluziju subklavije. Rezultate multivarijatne analize imaju ograničenu vrijednost zbog malog broja ispitanika.

Zaključak: Uspoređujući ovaj pregled sa sličnim istraživanjima u drugim centrima većina demografskih i kliničkih pokazatelja nisu pokazivali značajne razlike. Tehnički uspjeh u našem centru postignut je u 85\% zahvata, dok je u drugim studijama iznosio između 93\% i 98\%. Ženski spol identificiran je kao nezavisni rizični čimbenik premda se u literature muški spol navodi kao rizičan. Iako se hiperlipidemija navodi kao poznati rizični čimbenik za razvoj ateroskleroze, nije pokazala statističku značajnost u univarijatnoj analizi. Ovo istraživanje omogućilo nam je dublji uvid u karakteristike pacijenata liječenih u našem centru te pokazalo na kojim poljima postoji mjesta za napredak.

KLJUČNE RIJEČI: stenoza subklavije, potključna arterija, okluzija, endovaskularne intervencije, hipertenzija, spol, pušenje, hiperlipidemija, stentiranje, angioplastika 


\section{INTRODUCTION}

Peripheral arterial disease (PAD) is a condition characterized by narrowing of the arteries which do not supply the brain and heart (peripheral arteries). Atherosclerosis is considered to be the primary underlying cause of PAD. Risk factors such as hypertension, hyperlipidemia, diabetes and tobacco abuse promote the formation of atherosclerotic lesions. Subclavian artery (SA) stenosis is a relatively rare form of PAD, usually present in patients who already suffer from PAD on other vessels, most often lower extremity arteries. Other causes and conditions associated with SA stenosis include various forms of arteritis, thoracic outlet syndrome, fibromuscular dysplasia, and neurofibromatosis ${ }^{1,2}$. The prevalence of subclavian stenosis in general population is around $2 \%$. The prevalence is markedly higher in patients with PAD, with estimates ranging from $11.5 \%$ to $19 \%$. In patients without PAD the prevalence of subclavian stenosis is $1.5 \%$. It is $4.3 \%$ in patients with hypertension, $4.3 \%$ in patients with a history of smoking and $7.6 \%$ in patients with cerebrovascular disease ${ }^{1,2,3,4}$. This condition is usually asymptomatic due to the slow progression of atherosclerotic plaques and the abundant collateral circulation associated with the circle of Willis ${ }^{5}$. The symptoms in symptomatic patients include claudication, muscle fatigue and rest pain. They appear sooner and are more prominent if other vessels are affected. In the case of a severe stenosis proximal to the vertebral artery (VA) the distal SA is supplied by blood flowing reverse from VA, a condition known as subclavia steal syndrome (SSS). It may be categorized as complete (with a reverse flow in VA during the entire cardiac cycle) or partial (with a reverse flow only during systole) ${ }^{6}$. SSS may result in vertebrobasilar insufficiency, manifesting symptoms as vertigo, syncope, headache, diplopia, blurred vision, dysarthria, tinnitus etc. ${ }^{5,7,8,9}$.

The diagnosis of SA stenosis is established by detecting different systolic blood pressure between the two arms (difference greater than $15 \mathrm{mmHg}$ ) and by duplex ultrasound which can estimate the grade of stenosis. The exact dimensions of stenosis are determined by computed tomography (CT) angiography and digital subtraction angiography (DSA). Further diagnostic procedures may include magnetic resonance imaging (MRI) with or without angiography ${ }^{7,10}$.

Treatment of SA stenosis is usually reserved for symptomatic patients and includes open surgery and endovascular approach with percutaneous transluminal angioplasty (PTA) and/or stenting. The current treatment of choice is endovascular approach which combines PTA and stenting as its noninvasive nature yields faster recovery and less complications ${ }^{10}$.

The aim of this study was to examine the characteristics of SA atherosclerotic lesions in patients who underwent endovascular procedure and their relationship with known risk factors. Additional aim was to assess clinical and procedure characteristics of patients and compare them with similar experiences from other centers.

\section{PATIENTS AND METHODS}

We conducted a retrospective single center review of patients treated with endovascular procedure for SA stenosis and/or occlusion. All patients diagnosed and treated at the Department of Radiology of University Hospital Centre Zagreb, Croatia from January 2010 to December 2020 were included. A computer search using Radiologic Informatic System (RIS) database in our center was performed to identify the patients and obtain clinical and treatment details. Inclusion criteria included the patients who underwent endovascular procedures due to atherosclerotic stenosis and/or occlusion of SA. A total of 53 patients were detected. Three patients were excluded due to the arteritis origin of the stenosis, leaving 50 patients suitable for analysis.

\section{STATISTICAL ANALYSES}

Participants' characteristics were analyzed using descriptive statistics. Normal distribution was assessed using Shapiro-Wilk test. Categorical variables were analyzed using the Chi-square test. Univariate logistic regression was used to calculate unadjusted odds ratios of factors associated with level of stenosis. Factors with $\mathrm{P}<.10$ on univariate analysis were included in multivariate analyses. Factors with $\mathrm{P}<.05$ on multivariate analysis were considered significant. All tests were 2-tailed. Data analysis was performed with SPSS Version 20.

\section{RESULTS}

Among the 50 studied patients there was equal number of women and men. The mean age at the time of the first intervention was $62 \pm 8$ years. All except 8 patients were symptomatic. In asymptomatic patients endovascular procedure was undertaken prior to ipsilateral carotid endarterectomy. The most common symptoms were paresthesia (32\%), vertigo (30\%), muscle fatigue $(24 \%)$ and rest pain (22\%). 58\% of patients presented with Subclavian steal syndrome. Only two patients developed critical limb ischemia.

The most common comorbidities and risk factors present in selected patients were hypertension $76 \%$, smoking $60 \%$, hyperlipidemia $60 \%$ and coronary artery disease $22 \%$. (Table 1 ) Two patients suffered from renal insufficiency and two other from systemic lupus. Mean number of comorbidities per patient was 4,4 . 
Table 1. Comorbidities and risk factors in 50 patients who underwent endovascular treatment for $S A$ stenosis andlor occlusion

\begin{tabular}{|l|c|c|}
\hline Comorbidity or risk factor & Number of patients & $\%$ \\
\hline Hypertension & 38 & 76 \\
\hline Smoking & 30 & 60 \\
\hline Hyperlipidemia & 30 & 60 \\
\hline Coronary arterial disease & 11 & 22 \\
\hline $\begin{array}{l}\text { Endovascular procedure on any } \\
\text { other vessel }\end{array}$ & 10 & 20 \\
\hline Diabetes & 10 & 20 \\
\hline Internal carotid artery stenosis & 8 & 16 \\
\hline Stroke & 8 & 16 \\
\hline Neoplasm & 8 & 16 \\
\hline
\end{tabular}

A total of 50 SA lesions were detected, 37 stenoses, of which 23 subocclusive, and 13 occlusions. Of those, 39 were on the left and 11 on the right. Mean length of lesions was $21 \pm 11 \mathrm{~mm}$. Only 6 lesions were 3 to $5 \mathrm{~cm}$ long. Most lesions were situated in the prevertebral segment of SA, only 4 were in distal segments. Mean grade of stenosis, without subocclusion, was 73\% (IQ 60$80 \%)$. With subocclusion and occlusion mean grade of stenosis was $92 \pm 13 \%$.

The management of patients included clinical examination coupled with bilateral arm pressure measurement. 28 patients were further evaluated using CT angiography. DSA was performed in all the patients in the same act as intervention.

The lesions were treated with 59 endovascular procedures, 9 reinterventions among them. Six patients had an in-stent stenosis which warranted reintervention. One patient had 4 interventions from 2016 to 2018. Right transfemoral approach was the most frequently used (62\%), followed by left brachial approach (17\%). PTA with stenting (primary stenting) was performed in 43 procedures, using 39 balloon-expandable stents and 4 self-expanding ones. PTA alone was done in 12 patients and the procedure was halted after just DSA in 4 cases due to impassable calcifications. Six in- stent stenoses were detected and two stent-in-stent interventions were carried out.

Mean diameter of the stents was $7.7 \pm 1.3 \mathrm{~mm}$, and mean stent length was $26.85 \pm 13 \mathrm{~mm}$.
Technical success was achieved in $85 \%$ of procedures. In 9 patients it was impossible to place the stent and/or perform PTA due to the calcified plaque which proved impassable for the guiding wire. No embolic complications were encountered and only 10 local complications were detected: 4 femoral hematomas, 4 brachial hematomas, 1 cubital hematoma and 1 SA dissection. The fact that the majority of patients from this study weren't followed in our institution made it impossible to obtain data concerning follow up and to estimate the mid and long- term patency. For the purpose of the analysis of correlation of risk factors and severity of stenoses, North American Symptomatic Carotid Endarterectomy Trial (NASCET) method for calculating the grade of stenosis was used. Additionally, subocclusive stenoses were numerically categorized as $99 \%$ stenoses and occlusions as $100 \%{ }^{2,11,12}$. In logistic regression model subocclusive stenosis and complete occlusions were analyzed as a single category of dependent variable.

After univariate analysis 3 items were detected suitable for multivariate logistic regression (Table 2 ).

The multivariate regression model (Table 3 ) was statistically significant $\chi^{2}(4, N=50)=17.94, \mathrm{p}<0.01$, explaining $42.7 \%$ of variance (Nagelkerke $\left.R^{2}=.427\right)$. Female gender $(\mathrm{p}<0.05)$, hypertension $(\mathrm{p}<0.05)$ and smoking status $(\mathrm{p}<0.05)$ were independently associated with occlusion. Women had 7.7 times the odds of developing occlusion compared to males. Moreover, patients with history of hypertension were 5.1 times more likely to develop occlusion. Smoking was associated with 7.8 higher chances to develop occlusion. The results of multivariate analysis should be interpreted with caution due to the small sample size.

Table 2. Univariate analysis

\begin{tabular}{|l|l|}
\hline & Univariate OR $(95 \% \mathrm{CI})$ \\
\hline Age & $1,003(0,929-1,082)$ \\
\hline Female gender & $6,769(1,605-28,542)^{*}$ \\
\hline Smoking & $5,000(1,363-18,348)^{*}$ \\
\hline Hypertension & $3,222(0,830-12,509)^{*}$ \\
\hline Diabetes & $0,569(0,134-2,409)$ \\
\hline Hyperlipidemia & $0,432(0,115-1,622)$ \\
\hline
\end{tabular}

${ }^{*} \mathrm{p}<0.1$ has been considered significant

Table 3. Multivariable logistic regression, $\chi 2=17.94, R$ square $=42.7 \%$.

\begin{tabular}{|c|c|c|c|c|c|c|c|c|c|}
\hline \multicolumn{10}{|c|}{ Variables in the Equation } \\
\hline & & \multirow[b]{2}{*}{$\mathrm{B}$} & \multirow[b]{2}{*}{ S.E. } & \multirow[b]{2}{*}{ Wald } & \multirow[b]{2}{*}{$\mathrm{df}$} & \multirow[b]{2}{*}{ Sig. } & \multirow[b]{2}{*}{$\operatorname{Exp}(B)$} & \multicolumn{2}{|c|}{ 95\% C.I.for $\operatorname{EXP}(\mathrm{B})$} \\
\hline & & & & & & & & Lower & Upper \\
\hline Step & Female gender & 2,040 &, 825 & 6,119 & 1 &, 013 & 7,692 & 1,528 & 38,734 \\
\hline & Smoking & 2,057 &, 822 & 6,254 & 1 &, 012 & 7,821 & 1,560 & 39,207 \\
\hline & Hypertension & 1,636 & ,897 & 3,329 & 1 &, 068 & 5,134 & ,886 & 29,766 \\
\hline & Constant & $-2,248$ & 1,024 & 4,819 & 1 &, 028 & , 106 & & \\
\hline
\end{tabular}




\section{DISCUSSION AND CONCLUSION}

Subclavian artery stenosis can lead to serious morbidity, endangering the upper extremities, brain and the heart. Despite that, compared to other sites of atherosclerotic stenosis such as carotid or femoral arteries, the issue of SA seems somewhat neglected. The treatment for SA stenosis initially consisted of open surgery, developed in the 1950-s, carrying numerous complications with it. PTA followed in the 1970-s, but the issues of long term patency and restenosis remained a challenge. Since its introduction in the early 1990s endovascular procedure involving stenting proved to be an effective and popular treatment for SA stenosis, as well as for other sites. Its simplicity, effectiveness and shorter hospital stay coupled with fewer complications compared to open surgery make it appealing to physicians and patients alike $10,13,14,15$.

Comparing this review with other similar studies ${ }^{14,15,16}$, most of the clinical and demographic indicators were inconspicuous. We observed a higher percentage of occlusions in our cohort (26\%) compared to other studies (11\% and $14 \%)^{15,16}$. However, we detected a significant difference in the technical success rate. Technical success was achieved in $85 \%$ of the procedures in our center, whereas in other studies it was markedly higher, 93\% in De Vries et al., 96\% in Brountzos et al. and 98\% in Patel et al. respectively. These differences may be due to the higher number of occlusions in our group of patients than in the compared studies.
Analysing comorbidities associated with the grade of stenosis only two well known risk factors were detected, hypertension and smoking ${ }^{17,18}$. Female gender was identified as additional independent risk factor although the relevant literature indicates male gender as the risk factor ${ }^{19}$. This may be due to the small sample size used for this analysis.

Although hyperlipidemia is a known risk factor for atherosclerotic stenosis, it did not reach statistical significance in univariate analysis. However, certain studies had so far observed protective effect of higher levels of high-density lipoprotein (HDL) against atherosclerotic stenosis ${ }^{20}$. It is important to note that the results of multivariate analysis are presented regardless of the small sample size.

To conclude, it appears that our patients correspond well with other patient populations considering risk factors, age at the time of procedure and comorbidities. However, this research provided a much needed insight into the effectiveness of interventions undertaken in our center. It is further important to assess the possible reasons for this discrepancy and the possibilities of improvement.

Finally, it is important to note that SSS is often overlooked and left undertreated, and yet the endovascular treatment is a simple and effective method, which when applied successfully can greatly improve the patient's quality of life.

\section{REFERENCES:}

1. Caesar-Peterson S, Bishop MA, Qaja E. Subclavian Artery Stenosis. [Updated 2021 Mar 3]. In: StatPearls [Internet]. Treasure Island (FL): StatPearls Publishing; 2021 Jan-. Available from: https://www.ncbi.nlm.nih.gov/books/ NBK470221/

2. Mousa AY, Morkous R, Broce M, et al. Validation of subclavian duplex velocity criteria to grade severity of subclavian artery stenosis. J Vasc Surg. 2017;65(6):1779-1785.

3. English JL, Carell ES, Guidera SA and Tripp HF. Angiographic prevalence and clinical predictors of left subclavian stenosis in patients undergoing diagnostic cardiac catheterization. Cathet. Cardiovasc. Intervent. 2001; 54: 8-11. https://doi.org/10.1002/ccd.1230

4. Gutierrez GR, Mahrer P, Aharonian V, Mansukhani P, Bruss J. Prevalence of Subclavian Artery Stenosis in Patients with Peripheral Vascular Disease. Angiology. 2001;52(3):189-194. doi:10.1177/000331970105200305

5. Psillas G, Kekes G, Constantinidis J, Triaridis S, Vital V. Subclavian steal syndrome: neurotological manifestations. Acta Otorhinolaryngol Ital. 2007;27(1):33-37.

6. Labropoulos N, Nandivada P, Bekelis K. Prevalence and impact of the subclavian steal syndrome. Annals of surgery. 2010 Jul 1;252(1):166-70.

7. Kargiotis $\mathrm{O}$ et al. Subclavian Steal Syndrome with or without Arterial Stenosis: A Review. J Neuroimaging 2016;26:473-480. DOI: 10.1111/jon.12371

8. Ibrahimagić O Ć, Smajlović DŽ, Dostović Z, Iljazović A, Kunić S. Interarm skin temperature differences: manifestation of subclavian steal syndrome? Neurol Sci. 2018 Jun;39(6):1143-1144. doi: 10.1007/s10072-018-3291-8.

9. Hayat UK, Khawaja AZ, Jones RG, Inston NG. Blurring of vision in subclavian steal syndrome associated with an upper arm arteriovenous fistula. J Vasc Access. 2017 Mar 21;18(2):e20-e21. doi: 10.5301/jva.5000641.

10. Rafailidis V, Li X, Chryssogonidis I, Rengier F, Rajiah P, Wieker CM, Kalva S, Ganguli S, Partovi S. Multimodality Imaging and Endovascular Treatment Options of Subclavian Steal Syndrome. Can Assoc Radiol J. 2018 Oct 11. pii: S0846-5371(18)30140-2. doi: 10.1016/j. carj.2018.08.003. 
11. Szczerbo-Trojanowska M, Jargiełło T, Drelich-Zbroja A. Management of carotid stenosis. History and today. J Ultrason. 2013;13(52):6-20. doi:10.15557/JoU.2013.0001

12. Johansson E, Fox AJ. Carotid Near-Occlusion: A Comprehensive Review, Part 1--Definition, Terminology, and Diagnosis. AJNR Am J Neuroradiol. 2016;37(1):2-10. doi:10.3174/ajnr.A4432

13. Ochoa VM, Yeghiazarians Y. Subclavian artery stenosis: A review for the vascular medicine practitioner. Vascular Medicine. 2011;16(1):29-34. doi:10.1177/1358863X10384174

14. Brountzos EN, Petersen B, Binkert C, Panagiotou I, Kaufman JA (2004) Primary stenting of subclavian and innominate artery occlusive disease: a single center's experience. Cardiovasc Intervent Radiol 27(6): 616-623

15. Patel SN, White CJ, Collins TJ, et al. Catheter-based treatment of the subclavian and innominate arteries. Catheter Cardiovasc Interv 2008; 71: 963-968.

16. De Vries JP, Jager LC, Van den Berg JC, et al. Durability of percutaneous transluminal angioplasty for obstructive lesions of proximal subclavian artery: long-term results. J Vasc Surg 2005; 41: 19-23
17. Mast H, Thompson JL, Lin IF, Hofmeister C, Hartmann A, Marx P, Mohr JP, Sacco RL. Cigarette smoking as a determinant of high-grade carotid artery stenosis in Hispanic, black, and white patients with stroke or transient ischemic attack. Stroke. 1998 May;29(5):908-12. doi: 10.1161/01. str.29.5.908. PMID: 9596233.

18. Ji R, Pan Y, Yan H, et al. Current smoking is associated with extracranial carotid atherosclerotic stenosis but not with intracranial large artery disease. BMC Neurol 17, 120 (2017). https://doi.org/10.1186/s12883-017-0873-7

19. Stoberock K, Debus ES, Atlihan G, Daum G, LarenaAvellaneda A, Eifert S, Wipper S. Gender differences in patients with carotid stenosis. Vasa. 2016 Jan;45(1):11-6. doi: 10.1024/0301-1526/a000490. PMID: 26986705

20. Shadman R, Criqui MH, Bundens WP, Fronek A, Denenberg JO, Gamst AD, et al. Subclavian artery stenosis: prevalence, risk factors, and association with cardiovascular diseases. J Am Coll Cardiol. 2004 (44), pp. 618-623 